\title{
Effect of Climate Change on Apple Productivity
}

\author{
K.K. Pramanick ${ }^{1, *}$, K.K. Jindal ${ }^{2}$, Girish Sharma ${ }^{3}$, A.K. Shukla ${ }^{1}$ \\ ${ }^{1}$ Indian Agricultural Research Institute (IARI) Regional Station (CHC), India \\ ${ }^{2}$ UGC, Shoolini Institute of Life Sciences \& Business Management (SILB), Affiliated to Himachal Pradesh University (HPU), India \\ ${ }^{3}$ Dr. Yashwant Singh Parmar University of Horticulture and Forestry (DRYSPUHF), India
}

Copyright $\bigcirc 2017$ by authors, all rights reserved. Authors agree that this article remains permanently open access under the terms of the Creative Commons Attribution License 4.0 International License

\begin{abstract}
India with its unique agro climate conditions favours cultivation of number of fruits. For decades together typical temperate fruits like apple, pear, stone and nut fruits were grown with adequate production and productivity. However, during the past 10-15 years on account of global warming many of the sites which were potential hub for temperate fruit cultivation have been rendering unfit for their cultivation. The productivity of temperate fruits especially apple in Himachal Pradesh is declining at a faster rate. Average yield of apple in India has been estimated at about $7.0 \mathrm{t} / \mathrm{ha}$ which is far below the level of $30 \mathrm{t} / \mathrm{ha}$ in most of advanced countries. The productivity has also not kept pace with the expansion in area under temperate fruits due to various biotic and abiotic problems faced by the farmers in the Himalayas. This has caused a serious concern not only to the hill farmer community but also to researchers, development agencies and policy planners. With the global warming, the decline in productivity is being mainly attributed to changing climatic scenario. It is clearly reflected that standard apple cultivar 'Starking Delicious' and 'Red Delicious' would not flower and fruit when chilling units are not adequately fulfil. Hence there is an urgent need to select appropriate low chill cultivars for plantation at low elevation location so that consistent yields are obtained and crop failures avoided. Results obtained revealed that cultivar 'Tropical Beauty' was the best genotype for the characters like plant height $(6.60 \mathrm{~m})$, plant spread $(5.67 \mathrm{~m})$, trunk girth $(64.50 \mathrm{~cm})$, tree volume $\left(111.20 \mathrm{~m}^{3}\right)$, leaf area $\left(60.67 \mathrm{~cm}^{2}\right)$, number of fruit set per unit shoot length $(15.25 \%)$, yield per plant $(15.82 \mathrm{Kg})$, fruit weight $(129.80 \mathrm{~g})$, total sugar $(8.48 \%)$ and non-reducing sugar $(1.92 \%)$. Cultivar 'Parlin's Beauty' was the best genotype for characters like fruit breadth, reducing sugar and was recorded as promising next to 'Tropical Beauty' for many desirable traits. Cultivar 'Chahla' was superior for high number of flowers per unit shoot length, shoot length, fruit length and long duration of flowering. Earliest flowering was observed in cultivars 'Anna'. Maximum phenotypic coefficient of variability was observed for fruit yield per plant. High heritability and high genetic advance indicated presence of additive gene action for these traits. To meet the bulk requirements of the processing units and
\end{abstract}

horticultural diversification, apple cultivation can be extended to mid hills by planting suitable low chilling cultivars. The low productivity of apple has become a serious concern for the farmers, research workers and development agencies at national and state level for the last two decades. Several factors can be attributed to the declining trend in productivity like expansion of apple cultivation to marginal areas, monoculture of Delicious varieties, declining standards of orchard management, improper chilling requirements and the fluctuating abnormal climatic conditions.

Keywords Apple, Bloom, Bud Break, Chill Units, Climate, Coefficient of Variation, Heritability, Low Chilling

\section{Introduction}

The phenomenon of global warming has now become fairly well entrenched. The hitherto set climatic pattern has become erratic affecting productivity of agricultural crops. Temperate fruit trees have been the most affected group. In their annual growth cycle these crops have a specific requirement of chilling during the winter months. This requirement is of late not being fully satisfied in most of the areas that were only marginally suitable for temperate fruit cultivation was reported by Wand [31].

Temperate fruit production in mild winter areas now days increased rapidly and even more new industries are being developed in regions where none previously existed. To date, in tropical highlands, fruit productivity and quality have been gradually improved through introduction and selection of better adaptable varieties based on their chilling requirements. To supplement the present existing knowledge gap in relation to the cultivar-environment interactions, the use of chill models to quantify chill accumulation during winter months would help in classifying the environment (potential growing areas) according to the amount of chill hours existed in that location reported by Abhayne [34]. 
The area in and around Shimla in Himachal Pradesh (India), is strictly not a temperate zone region, however, because of its altitude $(1900-2600 \mathrm{~m} \mathrm{ASL})$ it is able to support a fairly good production of temperate pome and stone fruits. Erratic winter chilling in some apple growing areas of late has raised alarming concerns about the continued sustenance of productivity of temperate fruits, particularly of apple, in the region. It will be pertinent to determine the extent of climate change in the region and its impact on productivity of apple trees.

India with its unique agro climate conditions favours cultivation of number of fruits. For decades together typical temperate fruits like apple, pear, stone and nuts were grown with adequate production and productivity. However, during the past 10-15 years on account of global warming many of the sites which were potential hub for temperate fruit cultivation have been rendering unfit for their cultivation. Under these situations, research efforts need to be intensified to enhance their productivity and to develop technologies for solving the production problems under adverse growing conditions.

Plant genetic resources are the backbone of crop improvement and some limited work on selection and cultivation of low chill apple, peach, plum and pear has been initiated in hill areas by Indian Agricultural Research Institute, Regional Station Shimla, (HP) and Dr YS Parmar University of Horticulture and Forestry, Nauni, Solan, India. The work to a larger extent has been confined to sub temperate and subtropical areas. The successful cultivation of low chill cultivars especially in marginal areas where insufficient chilling hours prevail and normal cultivars were failing to produce sufficient crop regularly has opened new vistas to try and cultivate these low chill cultivars due to weather vagaries major being fluctuating temperature during winter months. In India, better soil and weather conditions prevail in Himalayan foot hill that are conducive for growing low chilling varieties of fruits like pear, plum, peach etc. Researchers over more than two decades have evolved and tested number of low chill cultivars of apple fruit was reported by Sharma and Karkara[28]; Kuden and Kuden[17]; Bal [4]; Sharma et al.,[29] in India.

The area in and around Shimla in Himachal Pradesh (India), is strictly not a temperate zone region, however, because of its altitude $(1900-2600 \mathrm{~m} \mathrm{ASL})$ it is able to support a fairly good production of temperate pome and stone fruits. Erratic winter chilling in some apple growing areas of late has raised alarming concerns about the continued sustenance of productivity of temperate fruits, particularly of apple, in the region. It will be pertinent to determine the extent of climate change in the region and its impact on productivity of apple trees.

A number of models have been developed for calculating or estimating chilling/ chill units accumulated during winter months in a particular area reported by Allan[1]; Erez and Fishman[9]; Linsley-Noakes, et al.,[18]; Linvill[19]; Richardson et al.,[25]; Shallout and Unrath[27]; Fishman et al.,[10-11].
In the present paper, an attempt has been made to study the influence of changing climate, a major limiting factor of temperate fruits production especially apple and to analyze the main climatic variables in relation to apple productivity was reported by Anon [2].

The study of heritability and genetic advance are of paramount significance to estimate the scope of improvement by selection. Keeping in view the suitability of low chilling apple cultivars to the mid hill conditions and its genetic variability for further improvement were undertaken.

\section{Material and Methods}

Mostly apple cultivars in congenial conditions require 1000 or more chilling hours before flowering i.e. IARI Research Farm, Dhanda (location A), however some require around 250 chilling hours. To meet the bulk requirements of processing units and its diversification, low chill apple cultivation can be extended to mid hills (location B) by planting suitable cultivars.

Investigations were carried out during last one decade at experimental farm of Indian Agricultural Research Institute, Regional Station, Shimla, (location A) and Dr. Y.S. Parmar University of Horticulture \& Forestry, Nauni, Solan ,India (location B) on 11 low chilling apple cultivars namely, 'Anna' ,'Aziza' , 'Chahla', 'Early McIntosh', 'Maayan', 'Michal', 'Parlin's Beauty', 'Red June', 'Schlomit', 'Tamma' and 'Tropical Beauty' with one standard cultivar 'Red Delicious'. The plants under evaluation were 15 years old having uniform size, raised on seedling rootstock planted in a Randomized Block Design with five replications. Data was recorded on various characters and analyzed as described by Panse and Sukhatme [21].

Tree volume was calculated as methodology suggested by Westwood [32] while shoot length of $65 \mathrm{~cm}$ was taken for recording fruit set up per unit shoot length. Coefficients of variability were calculated as per the formula suggested by Burton and DeVane [5] while heritability, genetic advance and genetic gain were calculated as per Johnson et al., [14].

Positive Chill Unit (PSU) accumulation and Chilling Portion (DM) accumulation was obtained as described by Linsley-Noakes, et al. [18] and Anonymous [2] respectively.

Weather data were collected from the two automatic weather stations installed at two locations in the different research farm of the IARI Regional Station, Shimla. These locations were at variance from each other with respect to their micro-climates due to different aspects (Northern and Southern) as well as altitude. Data were also collected from the agro-meteorological section of the Central Potato Research Institute, Shimla. Positive Chill Unit (PSU) accumulation and Chilling Portion (DM) accumulation was obtained as described by Linsley-Noakes, et al. [1995] and Anonymous [2] respectively. The chilling units on a daily basis were ascertained from the hourly temperature data on 
the basis of the conclusions drawn from the Utah Model by Richardson et al.,[25] in Table 3.

Controlled conditions experiment was conducted to study the effect of chilling units on bud break. The potted plants of Starking Delicious apple were subjected to 500, 750, 1000, 1250 and 1500 chill units in a cold chamber maintained at $6^{\circ}$ $\pm 2^{\circ} \mathrm{C}$ with $8 \mathrm{~h}$ light and $16 \mathrm{~h}$ dark. After the treatments with specific chilling, the plants were transferred to a growth chamber maintained at $18^{\circ} \mathrm{C} \pm 2^{\circ} \mathrm{C}$ to record the response to bud break.

\section{Results and Discussions}

Data on the mean value of various plant growth, floral and fruit characters are presented in Table 1. The plant height values varied from $4.10 \mathrm{~m}$ in 'Anna' to $5.80 \mathrm{~m}$ in 'Tropical Beauty' and both differed from one another statistically. The values for other cultivars also showed marked variation. Cultivar, 'Tropical Beauty' also scored maximum trunk girth $(60.30 \mathrm{~cm})$ and tree volume $\left(74.10 \mathrm{~m}^{3}\right)$, whereas lowest values for these traits were recorded for' Early McIntosh' $\left(36.60 \mathrm{~cm}\right.$ and $28.70 \mathrm{~m}^{3}$, respectively. Minimum shoot length was recorded for 'Red Delicious' $(20.40 \mathrm{~cm})$ followed by 'Red June' $(20.40 \mathrm{~cm})$ though similar statistically.

In cultivar 'Chahla', maximum shoot growth $(40.40 \mathrm{~cm})$, followed by 'Aziza' $(36.40 \mathrm{~cm})$, showed statistical variation in character. Leaf area a growth determining factor varied from 30.20-40.50 $\mathrm{cm}^{2}$. Cultivar 'Parlin's Beauty' registered minimum value $\left(30.20 \mathrm{~cm}^{2}\right)$, while 'Tropical Beauty' $\left(40.50 \mathrm{~cm}^{2}\right)$ outscored other cultivars for this trait.

The observations pertaining to floral traits were recorded on days from bud burst to first flower opening, first flower opening to full bloom and number of flowers/unit of shoot length. Days from bud burst to first flower open was minimum for 'Red Delicious' (8.10), followed by 'Parlin's Beauty' (9.60) and both values were similar statistically, while 'Schlomit' and 'Maayan' took 14.20 and 13.20 days, respectively. Cultivar 'Chahla' (11.50) followed by 'Schlomit' (11.00) recorded maximum days from first flower open to full bloom, whereas 'Tamma' and 'Tropical Beauty' accomplished this event in minimum time period of 7.0 and 7.50 days respectively. Cultivar 'Chahla' (36.40), 'Tropical Beauty' (32.20) statistically produced same number of flowers per unit shoot length and showed no variation, while 'Tamma' (12.0) and 'Red June' (12.10) had less flower number. Similar result was obtained by Sharma et al., [29]; Gautam and Chauhan [12]; Subhadrabandhu and Watanawong, [30].

Fruit traits are the ultimate deciding factors that determine variation and its adoption by the orchardists. In the present study fruit yield per plant varied from 15.80 to $35.90 \mathrm{Kg} /$ plant. Cultivars 'Tamma' (15.80 Kg/plant) followed by 'Early McIntosh' and 'Red June' produced lower yield of $18.50 \mathrm{Kg}$ /tree and these cultivars differed from each other. Higher yield were observed for cultivar 'Tropical Beauty' (35.90 Kg/plant) followed by 'Michel'
(28.60 Kg/plant), 'Maayan' (28.60 Kg/plant) and 'Anna' (28.10 Kg/plant). Mean fruit weight ranged from $65.70 \mathrm{~g}$ in 'Red June' to $130.40 \mathrm{~g}$ in 'Tropical Beauty'. Other cultivars also showed inherent genetic variation except 'Red June' and 'Early McIntosh' where fruit weight was below $100 \mathrm{~g}$, other cultivars on fruit weight basis could be classified in the range of medium to large. Cultivars 'Red June', although registered lower values of other fruit traits but had maximum value of TSS content of $12.40^{\circ}$ brix, followed by 'Red Delicious' (11.90 'brix) and minimum content was observed in 'Schlomit' $\left(9.30^{\circ}\right.$ brix), titrable acidity ranged from 0.22 per cent in 'Anna' to 0.78 per cent in 'Tamma' and both differed statistically. The trait total sugar varied from 4.70-8.20 per cent, maximum value being obtained for 'Tropical Beauty', followed by 'Parlin's Beauty' (6.55\%), while 'Anna' had minimum (4.70\%) total sugar content.

Observations recorded on different variability parameters are detailed briefly in Table 2. It is evident from the data that phenotype coefficient of variation values for all the 18 traits were recorded to be higher than the genotype coefficient of variation values. The genotypic values ranged from 17.22-62.16 whereas, phenotypic values for the studied traits ranged from 18.82-63.84, indicated variation among the characters studied.

Both genotypic and phenotypic coefficient of variation values were higher for trait tree volume $\left(62.16 \mathrm{~m}^{3}\right.$ and $\left.63.84 \mathrm{~m}^{3}\right)$ whereas, were minimum $\left(17.22^{0}\right.$ brix and 18.82 ${ }^{0}$ brix) for total soluble solid contents. Among heritability estimates values varied from a low of 38.24 per cent (plant spread) to a high of 82.36 per cent for character fruit yield followed by fruit weight $(80.05 \%)$, fruit length $(72.05 \%)$ and number of fruits per plant $(70.22 \%)$. For these traits heritability was in the range from medium to slightly high, whereas for most other traits, values were in the medium range. Genetic trait advance values revealed variation for traits under observation was reported by Sharma et al., [29]. The values ranged from 17.54 to 65.44 , maximum value was recorded for fruit yield, next in sequence being fruit weight $(60.23 \mathrm{~g})$ and least being for plant spread $(17.54 \mathrm{~m})$. Values in general were in the range low to medium.

Study of genetic variability components and their estimation are very important and are pre-requisite for initiation of any systematic breeding programme. This becomes all the more important as selection is based on phenotypes, therefore it becomes mandatory to have an appropriate idea as to how they correspond to their genotype and related breeding values. Johnson et al., [14] studied the estimates of genetic components and environmental variability in soybean and highlighted the importance of heritability values along with the values of genetic gain, rather than heritability values alone, so as to have a sound selection.

The data related to variability parameters show high heritability along with medium to high genetic advance registered for characters viz. tree volume, leaf area, number of flowers per unit length, fruit set per unit length, number of fruits per plant, fruit weight, length and yield which 
indicates that selection would be effective for these characters in future breeding programme of low chill apple cultivars. Both high heritability and genetic advance reveals the presence of additive gene action for these traits as suggested by Johnson et al.,[14].

Perusal of the total chill units received in Shimla, H.P., India during the last five years of the study show that in none of the years the accumulation was less than 1000 chill units. This is well within the range for cultivation of apples. However, the year to year fluctuations are a matter of concern and a further long term study should be continued to fully understand the impact of global warming on chilling units' accumulation at Shimla, Himachal Pradesh (Table-3). Standard Delicious apple trees were grown at two locations, an ideal site $(2286 \mathrm{~m}$ amsl) and the marginal site $(1375 \mathrm{~m}$ amsl), designated as location $\mathrm{A}$ and $\mathrm{B}$ respectively. The temperature and full bloom data was recorded for both the sites and varied significantly. Similar observations were reported by Jindal and Mankotia[13]; Mankotia et al.,[20]. Two techniques were used to compare the chilling requirement of 'Starking Delicious' apple viz. i) accumulation of chilling hours below $7.2^{\circ} \mathrm{C}$ ii) determination of effective chill units to break the rest period by adopting Utah Model by Richardson et al.,[25]; Ashcroft et al., [3]; Kishore et al., [16].

Cultivar 'Red Delicious' at same location with lower chilling units requirement did not perform satisfactory as required chill units conditions were not met with. The data on chilling clearly shows that as the chill units (CU) increased from 300 to 1250 at site A the number of days taken for bud break decreased from 52 to 12 and average number of buds that sprouted rose from 1.2 to 4.6 site B which is a marginal site also showed variation as regards chill units accumulated and days for bud break and average number of buds sprouted (Table 4). When about $750 \mathrm{CU}$ were accumulated cultivars took about 31 days for bud break and 2.4 buds sprouted on an average. The two locations showed distinct variation and clear cut indication of climate on chill unit accumulation.

Under the controlled conditions study on the effect of different chilling units on bud break, the maximum days taken for bud break of potted apple plants were under 500 chill units (CU) treatment and minimum under $1500 \mathrm{CU}$ treatment. It was observed that with the increase in chill units, there was reduction in number of days required for bud break (Table 5).

Earlier, Young and Werner [33] reported Chill unit and growing degree hour requirements for vegetative bud break in six apple rootstocks. They observed that the forcing time for bud break was decreased steadily as chilling hours increased. The number of buds sprouted after the plants were subjected to growing conditions indicated that with the increase in chilling units there was an increase in number of sprouted buds. Kishore and Randhawa [15] also observed similar results in Malus species. Abhayne [34] described elaborately about the physiology of chilling temperature requirements for dormancy release and bud-break in temperate fruit trees grown at mild winter tropical climate.

Perusal of the total chill units received in Shimla during the five years of the study show that in none of the years the accumulation was less than 1000 chill units. This is well within the range for cultivation of apples. However, the year to year fluctuations are a matter of concern for productivity and a further long term study should be continued to fully understand the impact of global warming at Shimla which is depicted in Table-6.

Three types of ready reckoners have been developed for estimating chilling units received at any particular location. One is in tabular format which estimates daily positive chill units (PSU) on the basis of maximum and minimum temperatures by Linsley-Noakes et al., [18], the second is in a graph format from which total chill units perceived in a region are estimated on the basis of average temperature during the coldest month(s) by Byrne and Bacon, [6]. Both these chill unit estimation models do not conform to the temperature range encountered in the apple growing regions of Shimla. Moreover though it is widely acknowledged that during the initial stages of dormancy negative chilling can accrue, yet no provision for this has been made in these two models.

The third model known as the dynamic model reported by Fishman et al., [10-11] takes cognizance of sequence of temperature variations for allotting an arbitrary unit of chilling portion. This chilling portion is hypothetical and the theory apparently holds good for subtropical regions experiencing warm winters was supported by Abhayne [34],Fishman et al., [10-11]; Erez et al., [8]; Perez et al., [23]; Ramirez, et al, [24]. Moreover it considers reversal of chilling possible even during deep and post dormancy periods which does not explain why it becomes almost impossible to force dormant apple buds during the deep dormancy period.

Bud dormancy is a characteristic feature of temperate fruit trees that has helped them to escape cold injury to vegetative and floral organs was reported by Peereboom Soller [22], Abhayne [34]. These crops require some critical amount of winter chilling to break the dormant stage was reported by Saure [26]. Early dormancy is the period when it becomes increasing difficult to force the buds to grow when transferred to optimum growth temperatures - until finally it becomes impossible to force growth. This is the period (October to December under Shimla conditions) when negative chilling (Utah Model) or reversible intermediate product formation (Dynamic Model) takes place i.e. the chilling process is reversed in case high temperatures $\left(16^{\circ} \mathrm{C}\right.$ and above) occur during this period.

The period between January and the first week of February represents the period of deep dormancy during which it is not possible to force growth of dormant apple buds. No negative chilling units can accrue or degradation of the 'intermediate product' can occur during this or later period. Hence the ready reckoner exhibits the positive chill units ignoring the negative chill units of Utah Model for this period. The same was reported by Abhayne [34]. 
This ready reckoner overcomes all the shortcomings mentioned earlier in the previously developed models for estimation of chill unit accumulation. This ready reckoner cannot be claimed to be of universal applicability since the variation between a particular maximum-minimum temperature combination is dependent on the number of daylight hours. The concept being that the more the daylight hours at a given place the longer would be the period during which relatively higher temperatures would prevail hence lesser chill units are likely to accrue and vice-versa at such locations.

A comparison was sought to be made between the traditionally counted hours below $7^{\circ} \mathrm{C}$, positive chill units (PSU) of Linsley-Noakes et al., [18] Model, the Dynamic Model (DM) and the ready reckoner (RR) developed in this study (Table 6). The lowest chill accumulation was exhibited by the traditional model. The PSU model showed the highest chill accumulation. The RR exhibits chill unit accumulation less than that by the Linsley-Noakes et al., [18] model as it takes into account the negative chilling during the months of October to December. The other three models tend to overlook this aspect of negative chilling, while the traditional model also ignores chilling effect between temperatures $7^{\circ} \mathrm{C}$ and $12^{\circ} \mathrm{C}$.

At the IARI Regional Station, Shimla comparative investigations have been undertaken to study the influence of winter temperatures below $7^{\circ} \mathrm{C}$ on effective chill units (ECU), growing degree hours Celsius $\left(\mathrm{GDH}^{0} \mathrm{C}\right)$ requirements and physiological changes associated with the bud dormancy of 'Red Delicious' apple under two locations viz., location A (ideal apple growing conditions with an altitude of 2286 in amsl) and location B (marginal apple growing conditions with an altitude of $1375 \mathrm{~m}$ amsl). Using the Utah Model, the effective chill unit requirements for location A and B were 1208 and 1130, respectively. The quantitative analysis of physiological components indicated varying pattern during the course of dormancy. The effects of various chilling units on bud break and biochemical attributes in young potted apple plants were studied under controlled conditions. It has been observed that with the increase in chilling exposure, the days required for bud break were reduced

Climate change per se will have impact on economically important species like apple but livelihoods of farmers are being threatened treatment due to incomplete chilling, longer GDH, erratic irruptive rainfall, and snow in winter, more frequent hail storms and enhanced abiotic and biotic stresses. However, measure to adapt to these climate changes is critical for sustainable production. Increased temperature and weather vagaries will have more effect on reproductive biology reported by Abhayne [34]. The strategies had been identified and addressed to mitigate the adverse effects of weather and development of climate resilient plants species, like low chilling crops, culture practices and efficient use of water. Concerted and integrated efforts can convert challenges into opportunity.
Maximum chilling was accumulated during the months of December, January and February, accounting for nearly $80 \%$ (79.97\%) of the total chilling units accumulated during the winter months. Minimum chilling occurred in months of October and April. The chill units that were actually accumulated and those estimated from the ready reckoner were very closely correlated $\left(\mathrm{R}^{2}\right.$ values varying from 0.9993 to 0.9998 ). The overall $R^{2}$ between all the actually counted and estimated chill units was 0.9995 reported by Kishore et al.,[16].

\section{Conclusions}

It is clearly reflected that standard apple cultivar Starking Delicious (site A) and Red Delicious (site B) would not flower and fruit when chilling units are not adequately fulfill. Hence there is an urgent need to select appropriate low chill cultivars for plantation at location B so that consistent yields are obtained and crop failures avoided. To meet the bulk requirements of the processing units and horticultural diversification, apple cultivation can be extended to mid hills (location B) by planting suitable low chilling cultivars. High heritability and high genetic advance indicated presence of additive gene action for these traits. The genotypes could be used by selection or in future breeding programme. To meet the bulk requirements of processing units and its diversification, low chill apple cultivation can be extended to mid hills (location B) by planting suitable cultivars.

Study of genetic variability components and their estimation are very important and are pre-requisite for initiation of any systematic breeding programme. This becomes all the more important as selection is based on phenotypes, therefore it becomes mandatory to have an appropriate idea as to how they correspond to their genotype and related breeding values.

Meteorological data of two locations were analyzed and correlated to study the impact of changing climatic scenario on the overall temperate fruit productivity particularly apple in Himachal Pradesh. Effective chill unit accumulations (based on Utah Model were measured. The average apple productivity of the state was $6.94 \mathrm{t} / \mathrm{ha}$, increased slightly to $7.19 \mathrm{t} / \mathrm{ha}$ and then it declined to $4.17 \mathrm{t} / \mathrm{ha}$ and again increased to $10.5 \mathrm{t} / \mathrm{ha}$. Analysis of climatic variables under different locations indicated that there was decline in the accumulation or effective chill units (ECU) during winters from $1892 \mathrm{CU}$ to $1638 \mathrm{CU}$. The relationship between productivity and chill units, i.e. coefficient of correlation (r) was positive and statistically significant. The effect of various chilling, units $(500$ to $1,500 \mathrm{CU})$ on bud break in young potted-apple plants was studied under- controlled conditions. It was observed that with the increase in the chilling exposure, the bud break was advanced and improved. It is concluded that the quantum of chill unit accumulation is location specific and cannot be accurately estimated by any generalized estimation model. 
Table 1. Mean values for various plant, leaf, floral and fruit characters in different cultivars of apples

\begin{tabular}{|c|c|c|c|c|c|c|c|c|c|c|c|c|c|}
\hline & Anna & Aziza & Chahla & $\begin{array}{c}\text { Early } \\
\text { McIntosh }\end{array}$ & Maayan & Michel & $\begin{array}{l}\text { Parlin's } \\
\text { Beauty }\end{array}$ & $\begin{array}{c}\text { Red } \\
\text { Delicious }\end{array}$ & Red June & Schlomit & Tamma & $\begin{array}{c}\text { Tropical } \\
\text { Beauty }\end{array}$ & $\mathrm{CD}_{0.05}$ \\
\hline Plant height(m) & 4.10 & 4.40 & 4.78 & 4.70 & 5.20 & 4.50 & 5.60 & 5.10 & 4.30 & 5.20 & 4.30 & 5.80 & 0.44 \\
\hline Trunk girth $(\mathrm{cm})$ & 40.70 & 48.20 & 50.20 & 36.60 & 48.60 & 37.40 & 55.80 & 56.20 & 48.10 & 55.80 & 40.10 & 60.30 & 8.06 \\
\hline Tree volume $\left(\mathrm{m}^{3}\right)$ & 39.75 & 34.60 & 49.40 & 28.70 & 60.40 & 50.50 & 70.20 & 50.70 & 51.80 & 68.20 & 25.60 & 74.10 & 9.57 \\
\hline Shoot length $(\mathrm{cm})$ & 28.60 & 36.40 & 40.40 & 29.80 & 26.60 & 25.30 & 22.60 & 20.40 & 20.50 & 24.40 & 23.80 & 30.50 & 2.64 \\
\hline Leaf area $\left(\mathrm{cm}^{2}\right)$ & 36.50 & 33.70 & 32.30 & 36.60 & 38.50 & 36.70 & 30.20 & 32.50 & 30.20 & 32.40 & 32.90 & 40.50 & 2.07 \\
\hline $\begin{array}{l}\text { Days from bud burst } \\
\text { to } I^{\text {st }} \text { flower open }\end{array}$ & 12.30 & 10.40 & 12.00 & 9.70 & 13.10 & 12.10 & 9.60 & 8.10 & 10.40 & 14.20 & 10.00 & 10.60 & 1.95 \\
\hline $\begin{array}{l}\mathrm{I}^{\text {st }} \text { flower open to full } \\
\text { bloom }\end{array}$ & 10.20 & 9.10 & 11.50 & 8.30 & 10.50 & 9.20 & 9.20 & 8.30 & 8.10 & 11.00 & 7.00 & 7.50 & 1.86 \\
\hline $\begin{array}{l}\text { No. of flowers/unit } \\
\text { shoot length }\end{array}$ & 26.40 & 25.50 & 36.40 & 26.20 & 25.50 & 20.80 & 29.80 & 20.40 & 12.10 & 23.50 & 12.00 & 32.20 & 6.16 \\
\hline Fruit yield $\mathrm{Kg} /$ plant & 28.10 & 25.80 & 20.20 & 18.50 & 28.60 & 30.50 & 26.70 & 22.60 & 18.50 & 25.50 & 15.80 & 35.90 & 2.56 \\
\hline Fruit weight (g) & 112.8 & 110.2 & 105.2 & 85.60 & 100.30 & 107.2 & 120.50 & 105.70 & 65.70 & 120.30 & 106.40 & 130.40 & 7.43 \\
\hline TSS ${ }^{\circ}$ brix & 9.40 & 11.70 & 9.50 & 11.00 & 10.80 & 9.90 & 10.90 & 11.90 & 12.40 & 9.30 & 10.20 & 11.20 & 0.64 \\
\hline Acidity (\%) & 0.22 & 0.40 & 0.43 & 0.24 & 0.30 & 0.44 & 0.58 & 0.37 & 0.42 & 0.39 & 0.78 & 0.38 & 0.09 \\
\hline Total sugars $(\%)$ & 4.70 & 6.40 & 5.86 & 4.90 & 5.20 & 5.65 & 6.55 & 5.54 & 5.36 & 4.90 & 4.72 & 8.20 & 0.40 \\
\hline
\end{tabular}


Table 2. Variability parameters for various characters in low chilling apples

\begin{tabular}{|c|c|c|c|c|c|c|}
\hline \multirow{2}{*}{ Characters } & \multirow{2}{*}{ Range } & \multicolumn{2}{|c|}{ Coefficient of variation (\%) } & \multirow{2}{*}{$\begin{array}{c}\text { Heritability } \\
\text { broad sense (\%) }\end{array}$} & \multirow{2}{*}{$\begin{array}{l}\text { Genetic } \\
\text { advance }\end{array}$} & \multirow{2}{*}{ Genetic gain } \\
\hline & & Genotype & Phenotype & & & \\
\hline Plant height(m) & $4.10-5.80$ & 26.56 & 28.62 & 42.70 & 20.60 & 38.25 \\
\hline Plant Spread(m) & $3.40-6.90$ & 55.41 & 57.67 & 38.24 & 17.54 & 54.22 \\
\hline Trunk girth $(\mathrm{cm})$ & $36.60-60.30$ & 60.22 & 62.14 & 45.04 & 22.75 & 40.26 \\
\hline Tree volume $\left(\mathrm{m}^{3}\right)$ & $23.70-74.10$ & 62.16 & 63.84 & 62.56 & 30.10 & 47.85 \\
\hline Shoot length $(\mathrm{cm})$ & $20.40-40.40$ & 35.42 & 36.64 & 50.41 & 26.50 & 40.84 \\
\hline Leaf area $\left(\mathrm{cm}^{2}\right)$ & $30.20-40.50$ & 30.66 & 31.74 & 62.80 & 33.40 & 36.46 \\
\hline $\begin{array}{l}\text { Days from bud burst } \\
\text { to } I^{\text {st }} \text { flower open }\end{array}$ & $8.10-14.20$ & 22.56 & 23.84 & 60.44 & 28.63 & 40.42 \\
\hline $\begin{array}{l}\mathrm{I}^{\text {st }} \text { flower open to full } \\
\text { bloom }\end{array}$ & $7.00-11.50$ & 28.42 & 29.65 & 46.70 & 20.90 & 36.50 \\
\hline $\begin{array}{l}\text { No. of flowers/unit } \\
\text { shoot length }(65 \mathrm{~cm})\end{array}$ & $12.00-36.40$ & 44.28 & 46.30 & 61.26 & 27.34 & 37.80 \\
\hline $\begin{array}{l}\text { No. of fruit set/unit } \\
\text { length }(65 \mathrm{~cm})\end{array}$ & $3.06-12.46$ & 45.06 & 47.28 & 58.72 & 35.40 & 68.54 \\
\hline No. of fruits/plant & $30.00-170.0$ & 56.22 & 58.45 & 70.22 & 26.42 & 75.67 \\
\hline Fruit weight (g) & $65.70-130.40$ & 32.52 & 34.44 & 80.05 & 60.23 & 60.22 \\
\hline Fruit length $(\mathrm{cm})$ & $4.24-6.74$ & 22.36 & 23.05 & 72.05 & 54.50 & 40.36 \\
\hline Fruit breadth $(\mathrm{cm})$ & $4.96-7.58$ & 19.57 & 20.23 & 69.56 & 36.32 & 42.00 \\
\hline Fruit yield $\mathrm{Kg} /$ plant & $15.80-35.90$ & 68.35 & 69.86 & 82.36 & 65.44 & 65.54 \\
\hline $\mathrm{TSS}^{\circ}$ Brix & $9.30-12.40$ & 17.22 & 18.82 & 69.50 & 29.38 & 30.62 \\
\hline Titrable Acidity (\%) & $0.22-0.78$ & 51.26 & 52.47 & 46.44 & 20.12 & 32.84 \\
\hline Total sugars (\%) & $4.70-8.20$ & 28.56 & 29.44 & 55.62 & 26.44 & 58.54 \\
\hline
\end{tabular}

Table 3. Chill units based on daily maximum and minimum temperature $\left({ }^{\circ} \mathrm{C}\right)$ difference for high chill congenial conditions at IARI Regional Station, Amartara cottage, Shimla (H.P.)

\begin{tabular}{|c|c|c|c|c|c|c|}
\hline Month & 2006-07 & 2007-08 & 2008-09 & $2009-10$ & 2010-11 & $2011-12$ \\
\hline August & 0 & 0 & 0 & 0 & 0 & 0 \\
\hline September & 0 & 0 & 0 & 0 & 0 & 0 \\
\hline October & 32.5 & 1.5 & 13 & 9 & 6.0 & 5.0 \\
\hline November & 219 & 124 & 64.5 & 112.5 & 68.5 & 65.5 \\
\hline December & 464.5 & 449 & 226.5 & 496 & 369.0 & 350.5 \\
\hline January & 430.5 & 525 & 403.5 & 459 & 526.0 & 470.5 \\
\hline February & 446.5 & 431.5 & 325.5 & 438 & 400.0 & 375.5 \\
\hline March & 299.5 & 28 & 96.5 & 14 & 169.0 & 95.5 \\
\hline April & 0 & 0 & 44 & 0 & 100.0 & 10.5 \\
\hline $\begin{array}{l}\text { Total chill } \\
\text { units }\end{array}$ & 1892.5 & 1559 & 1173.5 & 1519.5 & 1638.5 & 1373 \\
\hline
\end{tabular}

Table 4. Effect of chilling unit (CU) on bud break of apple (Site B)

\begin{tabular}{|c|c|c|}
\hline Chill units & Days for bud break & Average buds sprouted \\
\hline 300 & 52 & 1.2 \\
\hline 500 & 46 & 2.1 \\
\hline 750 & 33 & 2.6 \\
\hline 1000 & 21 & 3.0 \\
\hline 1250 & 12 & 4.6 \\
\hline Mean \pm SE(M) & $32.8 \pm 3.26$ & $2.7 \pm 0.84$ \\
\hline
\end{tabular}


Table 5. Effect of chilling units (CU) on bud break of apple (Controlled conditions)

\begin{tabular}{|c|c|c|}
\hline Chill units & Days for bud break & Average buds sprouted \\
\hline 500 & 49 & 1.3 \\
\hline 750 & 31 & 2.4 \\
\hline 1000 & 19 & 2.6 \\
\hline 1250 & 16 & 3.2 \\
\hline 1500 & 14 & 4.3 \\
\hline Mean + SE $(M)$ & $25.8+6.25$ & $2.76+0.50$ \\
\hline
\end{tabular}

Table 6. Annual variations in chilling, productivity of apple in H.P. and mean winter temperatures at Shimla (1980 m Above Mean Sea Level), India

\begin{tabular}{|c|c|c|c|c|}
\hline Year & RR & DM & $\begin{array}{c}\text { Productivity } \\
\text { (tones/ha) }\end{array}$ & $\begin{array}{c}\text { Mean Annual Winter } \\
\text { Temperatures }\left({ }^{\circ} \mathrm{C}\right)\end{array}$ \\
\hline $1983-84$ & 1590 & 82 & 6.5 & 11.1 \\
\hline $2006-07$ & 1656 & 82 & 7.0 & 11.6 \\
\hline $2007-08$ & 1314 & 67 & 10.4 & 12.0 \\
\hline $2008-09$ & 1181 & 51 & 7.6 & 13.7 \\
\hline $2009-10$ & 1553 & 70 & 6.7 & 12.4 \\
\hline $2010-11$ & 1638 & 78 & 9.3 & 12.3 \\
\hline $2011-12$ & 1373 & 68 & 7.5 & 13.0 \\
\hline
\end{tabular}

\section{REFERENCES}

[1] Allan, P., 1999. Measuring winter chilling in areas with mild winters. Deciduous Fruit Grower, 49(10): S1-S10.Anonymous, 2012. Dynamic Model (Excel File).http://ucanr.org/sites/fruittree/How-to_Guides/ Dynamic_Model_-_Chill_Accumulation/

[2] Ashcroft, G.L., Richardson, E.A. and Seeley, S.D. 1977. A statistical method of determining chill unit and growing degree hour requirements for deciduous fruit trees. Hort Sci. 12:347-348.

[3] Bal, J.S. 2004. Genetic Resources of Plum under subtropical conditions of Punjab, India. Acta Hort. 662:147-150.

[4] Burton, G.W. and De Vane, R.W. 1953. Estimating in tall fescue (Festuca arundinacia) from replicated clonal material. Agron. J. 45:478-481.

[5] Byrne, D.H. and Bacon, T. 1992. Chilling estimation its importance and estimation. The Texas Horticulturist, 18(8): 5, 8-9.

[6] Erez, A. 2000. Temperate fruit crops in warm climates. Kluwer Academic Publisher, AA Dordrecht, the Netherlands. pp. 17-49.

[7] Erez, A., Fishman, S., Gat, Z. and Couvillon, G.A. 1988. Evaluation of winter climate for breaking bud rest using dynamic model. Acta Hort. 232:76-89.

[8] Erez. A. and Fishman, S. 1998. The Dynamic Model for chilling evaluation in peach buds. Acta Hort., 465: 507-510.

[9] Fishman, S., Erez, A. and Couvillon, G.A. 1987b. The temperature dependence of dormancy breaking in plants-computer simulation of processes studied under controlled temperatures. J. Theoretical Biol., 126: pp. 309321.

[10] Fishman, S., Erez, A. and Couvillon, G.A. 1987a. The temperature dependence of dormancy breaking in plants: Two-step model involving a co-operation transition. $J$. Theoretical Biol., 124: 473-483.

[11] Gautam, D.R. and Chauhan, J.S. 1986. Varietal variation in growth \& quality of fruit in some low chilling apple. (Malus $\mathrm{x}$ domestica borkh.) cultivars in mid hill conditions. P.7-10. In : T.R. Chadha, V.P. Bhutani \&J.L. Kaaul (eds.), Advances in research on temperate fruits, Dr. YS Parmar University of Horticulture \& forestry, Nauni Solan w.e.f. March 15-18, 1984.

[12] Jindal, K.K. and Mankotia, M.S. 2004. Impact of changing climatic conditions on chilling units, physiological attributes and productivity of apple in western Himalayas. Acta Hort. 662: 111-118.

[13] Johnson, H.W., Robinson, H.F. and Comstock, R.W. 1955. Estimates of genetic \& environmental variability in soybean. Argon. J. 47:134-318.

[14] Kishore, D.K. and Randhawa. S.S. 1984. Comparative chilling requirement of Malus species. In Advances in research on Temperate Fruits. T.R. Chadha, (Ed). Dr. Y.S. Parmar University of Horticulture and Forestry, Nauni, Solan, pp 95-98.

[15] Kishore, D.K., Pramanick, K.K., Singh, A.K., Singh, R. and Verma, J.K. 2014. Chilling Unit Accumulation at Shimla, Himachal Pradesh, India - a predominantly Apple (Malus X domestica Borkh) growing region. Intl. J. Fruit Sci.(00)1-12.

[16] Kuden, A.B. and Kuden,A.2004. Cherry (Prunus avium L.) Growing under subtropical conditions. Acta Hort. 662:171-174.

[17] Linsley-Noakes, G.C., Louw, M. and Allan, P. 1995. Estimating daily positive Utah chill units from maximum and 
minimum temperatures. J. of SA Soc. Hort. Sci., 5(1): 19-24.

[18] Linvill, D.E. 1990. Calculating chilling hours and chill units from daily maximum and minimum temperature observations. Hort.Sci., 25(1): 14-16.

[19] Mankotia, M.S., Chauhan, P.S., Sud, A. and Jindal, K.K.2004. Estimation of effective chilling hours and $\mathrm{GDH}^{\circ} \mathrm{C}$ requirement and its significance in predicting full bloom in Delicious apple. Acta Hort. 662:83-86.

[20] Panse, V.G. and Sukhatme, P.V. 1995. Statistical methods of agricultural workers. New Delhi: ICAR publications.

[21] Peereboom Soller, C.F. 1986. Predicting rest-breaking: principles and problems. Deciduous Fruit Grower, August: 302-308.

[22] Perez, F.J., Ormeno, J.N., Reynaert, B. and Rubio. S. 2008. Use of the Dynamic Model for the Assessment of winter chilling in a temperate and a subtropical climate zone of Chile. Chilean J. of Agril. Res, 68: 198-206.

[23] Ramirez, L., Sagredo K.X. and Reginato. G.H. 2010. Prediction models for chilling and heat requirements to estimate full bloom of almond cultivars in the central valley of Chile. Proceedings VIII International Symposium on Temperate Zone Fruits in the Tropics and Subtropics. F.G. Herter, G.B. Leite, M.D.O.C.B. Raseira (Eds), 107-112.

[24] Richardson, E.A., Seeley S.D. and Walker. D.R. 1974. A model for estimating the completion of rest for 'Redhaven' and 'Elberta' peach trees. Hort.Sci., 9(1): 331-332.

[25] Saure, M.C. 1985. Dormancy release in deciduous fruit trees.
Hort. Rev., 7:239-300.

[26] Shallout, A.D. and Unrath. C.R. 1983. Rest completion prediction model for 'Starkrimson Delicious' apples. J. of Amer. Soc. Hort. Sci., 108(6): 957-961.

[27] Sharma, R.P. and Karkara, B.K. 2004. Performance of some cultivars of delicious apple in low altitude warmer valley areas of Shimla. Acta Hort. 662: 175-180.

[28] Sharma, G., Chua, G.D. and Sharma, O.C. 2004. Studies on evaluation and variability parameters in low chilling apples (Malus X domestica Borkh.). Acta Hort. 662: 157-162.

[29] Subhadrabandnu, S. and Watanawong Vijit, P. 1990. Preliminary study on forcing of flowering in apple (Malus sylvestis Mill.) var. Anna. Acta Hort. 279:269-273.

[30] Wand, S.J.E., 2000. Potential impacts of climate change on the deciduous fruit industry in the Western Cape. Proceedings of the Ninth Southern African Society for Horticultural Sciences Congress Nelspruit.

[31] Westwood, M.N. 1978. Temperate zone pomology. Portland Oregon, Timber Press, p.428.

[32] Young, E., \& Werner, D. J. (1985). Chill unit and growing degree hour requirements for vegetative bud break in six apple rootstocks. J. of Amer. Soc. Hort. Sci., 110, 411-413.

[33] Abayneh Melke (2015). The Physiology of Chilling Temperature Requirements for Dormancy Release and Bud-break in Temperate Fruit Trees Grown at Mild Winter Tropical Climate. Journal of Plant Studies; Vol. 4, No. $2 ; 110-156$. 